GSTARS بررسى كارايى توابع انتقال رسوب در مدل عددى

\author{
فاطمه زهرا اسدى، رامين فضل اولى" و عليرضا عمادى'

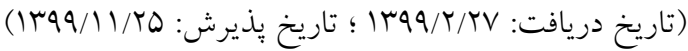

جكيده

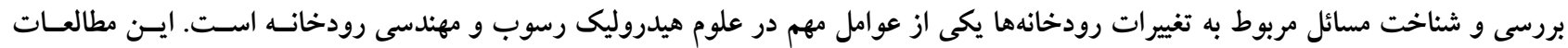

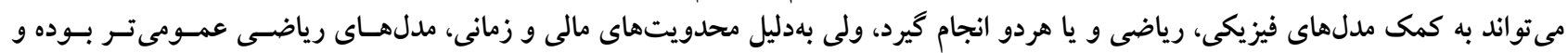

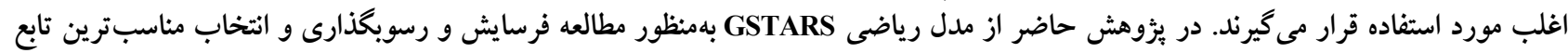

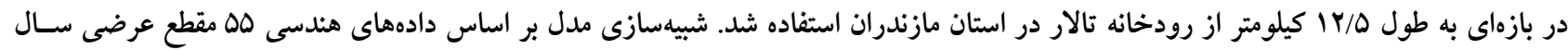

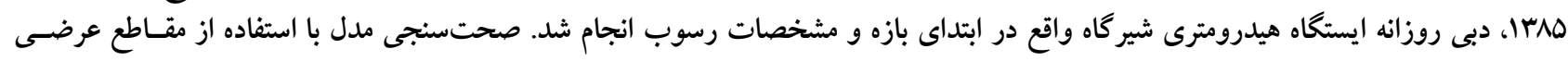

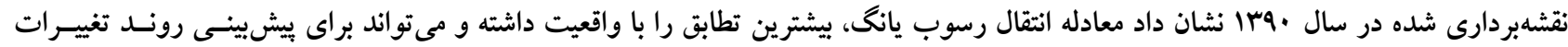

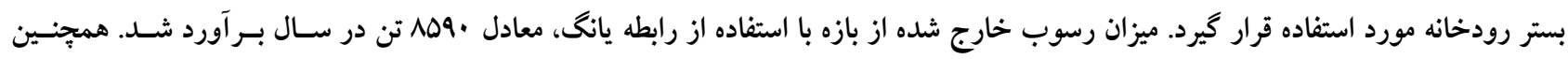

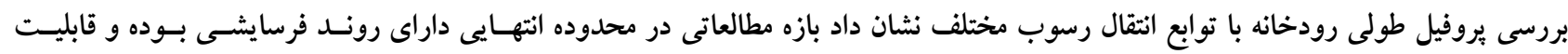
برداشت شن و ماسه را ندارد.

وازةهاى كليدى: تغييرات بستر، رودخانه تالار، شبيهسازى عددى، فرسايش و رسوبخذارى، واسنجى رسوبى. 
مدلهاى رياضى شامل مدلهاى يك، دو و سهبعدى هستند.

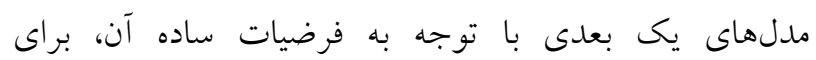
شبيهسازى رفتار رودخانه كه بسيار بيّيجيده است، كافى نيستند ولى اين مدلها تحت شرايط خاص مىتوانند نتايج قابل قبولى ارائه داده و مورد استفاده قرار كيرند. مدلهاى دو و سه بعدى، داراى بييجيدگى بيشترى هستند (9). همجنين با توجه به اينكه ابعاد واقعى سيستم در مدلهاى رياضى شبيهسازى مىشوند، اين مدلها با محدوديت مقياس مواجه نيستند ولى به اطلاعات بيشترى براى واسنجى و صحتسنجى نياز دارند. سانى (1/) با استفاده از مدل GSTARS2.1 به شبيهسازى ها كيلومتر از رودخانه تانا و ها كيلومتر شاخه فرعى تيكا اين رودخانه در كنيا يرداخت. هدف از اين مطالعه در واقع بررسى توزيع زمانى و مكانى رسوبات ورودى به مخزن سد ماسينگا در ياييندست رودخانه تانا، بود. شبيهسازى با استفاده از عم مقطع برداشت شده در سال 1919 و دادههاى هيدروليكى شامل دبى روزانه و دما در بالادست و سطح آب روزانه مخزن (در ياييندست بازه مورد مطالعه)، صورت گرفته و واسنجى مدل

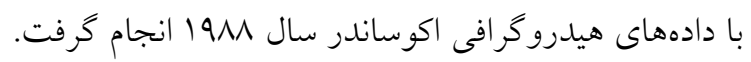
آبود و همكاران ( (1) به بررسى و ارزيابى مدلهاى مختلف براى

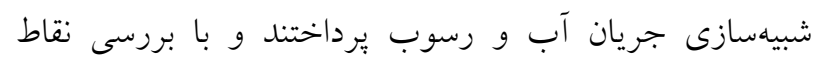
ضعف و قوت، مدلهاى مناسب براى بيشبينى دقيقتر يديدهاى مرتبط با انتقال رسوب را توصيه كردند. ايشان دو مدل GSTARS و HEC-6 را بهعنوان نرمافزارهاى موفق در زمينه بيشبينى الخوى رسوبخذارى مخازن بيشنهاد كردند. زراتى و اطاعت ( آY)، عملكرد مدلهاى رياضى GSTARS2 و Fluvial12 را در شبيهسازى رفتار رودخانهها مورد بررسى قرار دادند و اين دو مدل را قادر به شبيهسازى تغييرات تراز و همجنين عرض آبراهلها معرفى كرده و اظهار داشتند با اينكه معادلات اين مدلها يكبعدى هستند با كمك روابط اضافى قادر به شبيهسازى شبه سه بعلى رودخانهها هستند. گيبسون (1) با استفاده از مدل HEC-RAS مدلسازى بستر
رودخانه بهعنوان سيستمى يويا، بهطور بييوسته مكان و خصوصيات خود را برحسب زمان، عوامل طبيعى و گاه در اثر دخالت بشر تغيير مىدهد. اين منابع خداداى، تحت تأثير بديده فرسايش و رسوبخذارى دستخوش تغييرات گوناگونى مىشوند كه از آن جمله مىتوان به تغيير امتداد، جابهجايىهاى عرض و ورسي طولى، وقوع ميانبرها، تغيير نوع رودخانه، تغيير تراز بستر، تغيير

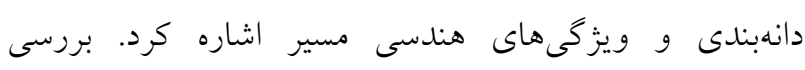
كزارشها و نشريات نشان مىدهد كه در بسيارى از موارد يديده فرسايش و رسوبخذارى و بيامدهاى آن عامل اصلى در تخريب سازههاى عرضى، تأسيسات هيدروليكى و بهويزه

سازههاى حفاظت و اصلاح مسير رودخانه بوده است (T) مطالعات فرسايش و رسوب ضمن شناخت و بيشبينى عملكرد رفتارى رودخانه اين امكان را فراهم مى آورد تا اثر اقدامات ساماندهى نيز مورد ارزيابى قرار كرفته و بهكمى تشخيص عوامل نايايدارى بتوان معيارهاى حفاظتى و اقدامات مهندسى مناسب را اعمال كرد. با استفاده از مدلهاى فيزيكى - هيدروليكى روابط تجربى متعددى براى بررسى و بيشبينى فرسايش و رسوبخذارى، ارائه شده است. اين روابط كه بر مبناى قوانين ديناميك و هيدروليك هستند با درنظر كرفتن خصوصياتى از قبيل دبى، سرعت، عمق لق لقين و سطح مقطع جريان، دانهبندى بستر، قطر ذرات رسوب، وزن مخصوص، لزجت و دماى آب بهدست آمدهاند. دادههاى مورد استفاده در اين معادلات بسيار زياده بوده و در بسيارى از ايستخاههاى آبسنجى جنين دادههايى به اندازه كافى يافت

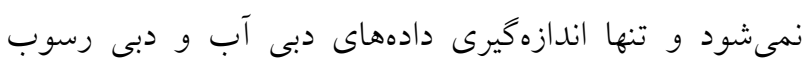
انجام مى گيرد. اين امر استفاده از اين روابط را دجار مشكل مى كند. بنابراين توسعه روشهاى كارآمد و دقيق براى برآورد ميزان رسوب كه محدوديتهاى مختلف نداشته باشد از اهميت زيادى برخوردار است. بههمين دليل در جند دهه اخير استفاده از مدلهاى كامبيوترى به نحو جشمثيرى توسعه يافته كه در نتيجة آن روند انجام محاسبات آسانتر و انجام تحليلها بسيار 
كانال مركب مورد تأييد قرار داد.

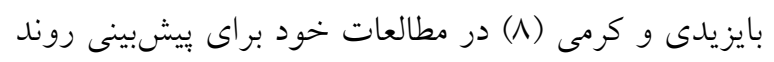

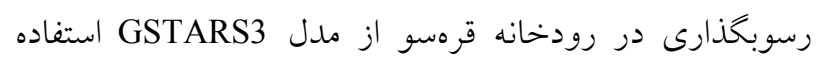

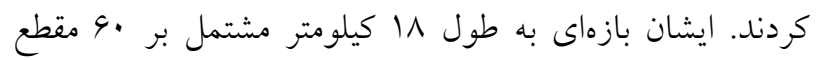

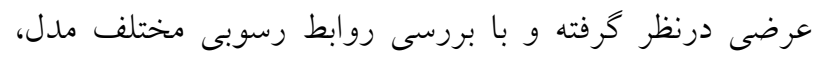

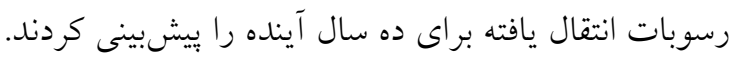

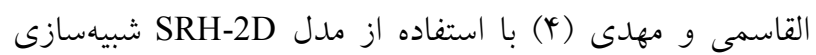

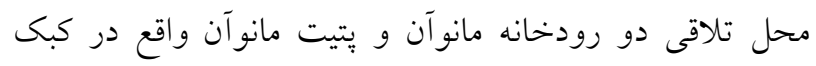

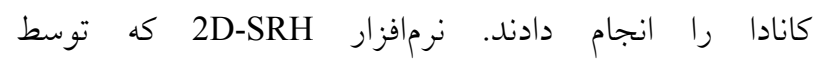
مؤسسه USBR توسعه داده شده است هيدروليك جريان و رسوب را بلصورت دوبعدى براى سيستمهاى رودخانههاى

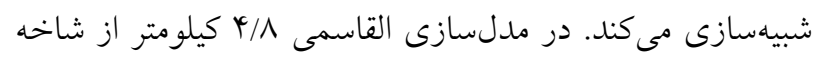

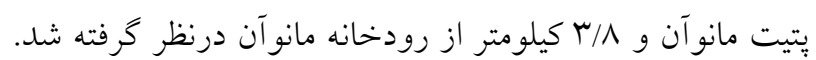
بستر رودخانه از جنس شن و ماسه بوده و معادلات انتقال

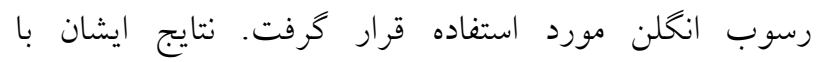
مشاهدات انجام شده در محدوده، تطابق داشته و مدل ايجاد شده بهطور صحيحى نشان داد در مناطقى كه سرعت كم بوده

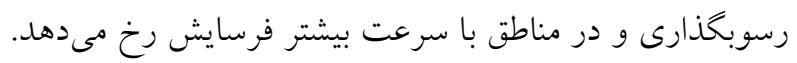

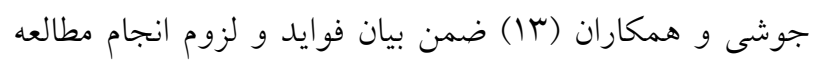

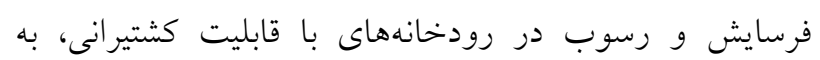

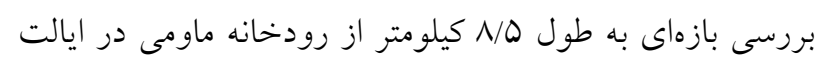

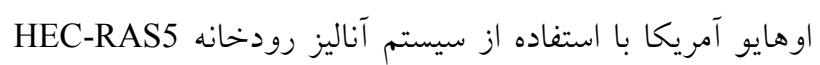

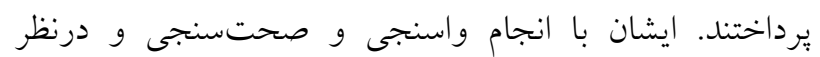

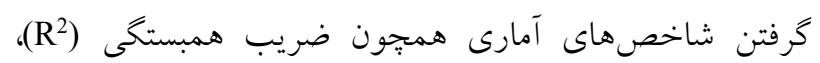
نسبت مجذور ميانخين مربعات خطا (RMSE) به انحراف معيار

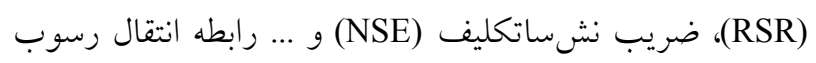
ميرييترمولر را انتخاب كردند. با استفاده از اين رابطه بيشترين

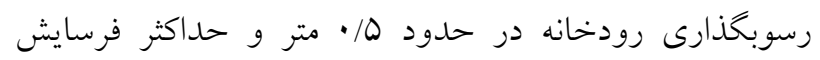

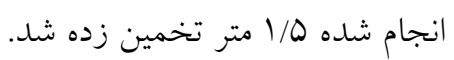

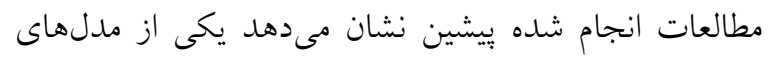

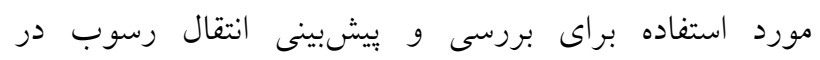

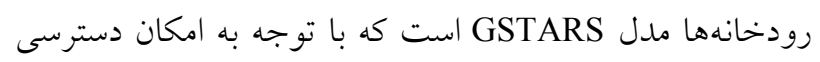

متحرك رودخانه كوليتز را انجام و اثرات رسوبحذارى درازمدت

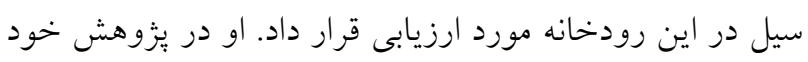
با توجه به بستر رودخانه كوليتز (وجود ماسه ريز، لاى و شن)

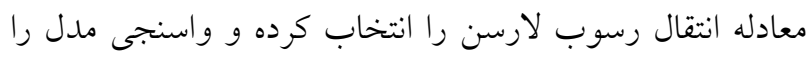
با جهار سرى دادههاى هيدروگرافى برداشت شده از رودخانه

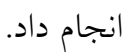
خدابخشى (ץ () كه در مطالعات خود به مقايسه مدلهاى GSTARS3 ور شبيهسازى رفتار رودخانه HEC-RAS سيستان يرداخت، با مقايسه نتايج بيان كرد كه مدل GSTARS

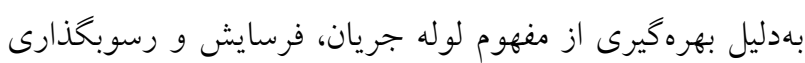
در مقاطع عرضى را بهتر از مدل HEC-RAS شبيهسازى كرده لونه البياتى (r) به مدلسازى و بيشبينى انباشت رسوب در مخزن سد كنير در مالزى با استفاده از مدل GSTARS3 يرداخت. وى جهت تحليل و نمايش نتايج از تلفيق نرمافزار

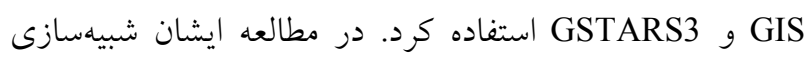
براى 19 سال و عملكرد مدل GSTARS3 با استفاده از

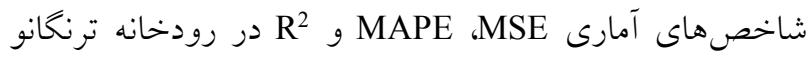

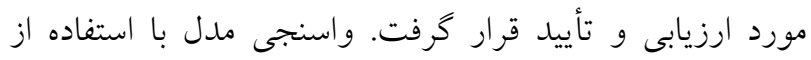

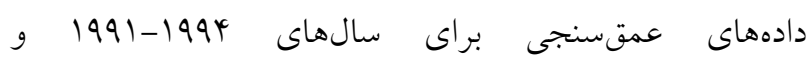
صحتسنجى مدل با استفاده از اطلاعات عمقسنجى 1991-

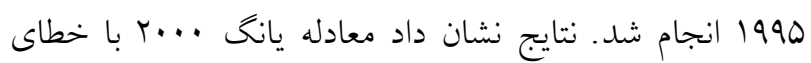

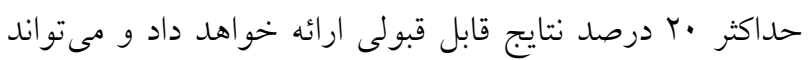
در مطالعات اين رودخانه مورد استفاده قرار گيرد.

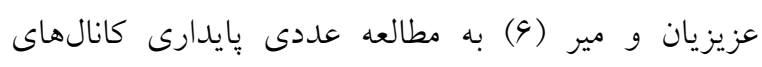
آبرفتى مركب با استفاده از نتايج تجربى و مدل GSTARS4

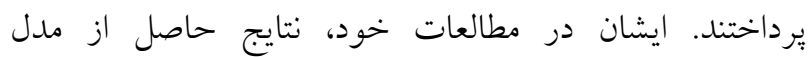

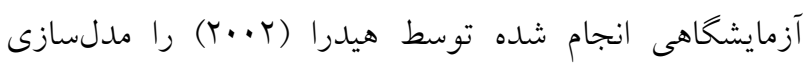
كرده و واسنجى مدل را بر اساس رقوم سطح آب، بارامترهاى نداى

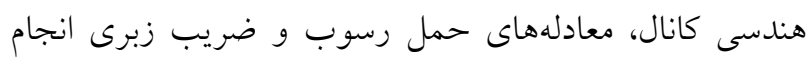

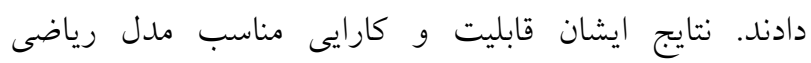
GSTARS4 
شد و سبس نسخههاى بعدى آن تحت عنوان GSTAR-1D، GSTARS4 gSTARS3 GSTARS2.1 GSTARS2.0

معرفى شدند (19)

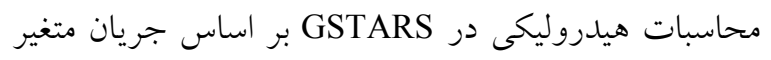
تدريجى است. رزيم جريان تركيبى و يرش هيدروليكى مىتواند

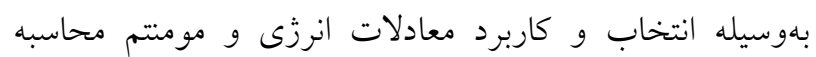

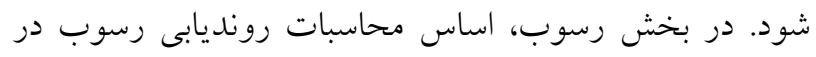

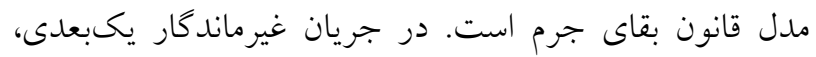

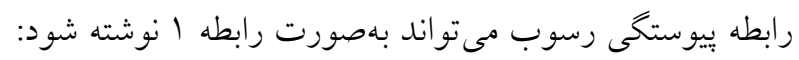
$\frac{\partial \mathrm{Q}_{\mathrm{s}}}{\partial \mathrm{x}}+\eta \frac{\partial A_{d}}{\partial t}+\frac{\partial A_{s}}{\partial t}-q_{s}=0$

كه در آن: 7 حجم رسوب در واحد حجم لايه بستر (تخلخل)، A Aم رسوبات بستر در واحد طول، As

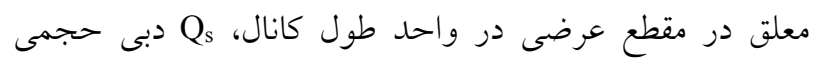
رسوب و qs رسوب جانبى ورودى.

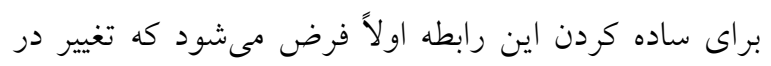
غلظت بار معلق در يكى مقطع عرضى خيلى كمتر از تغيير بستر

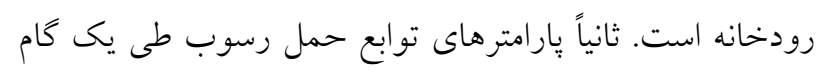

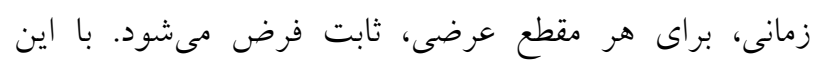

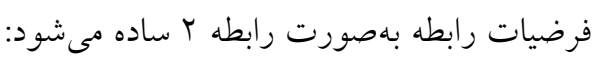

$\eta \frac{\partial A_{d}}{\partial t}+\frac{d Q_{s}}{\mathrm{dx}}=q_{s}$

كه رابطه غالب در GSTARS است و براى رونديابى رسوب در

رودخانها و جريان بهكار مىرود (19).

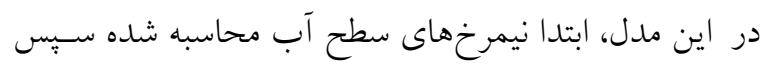

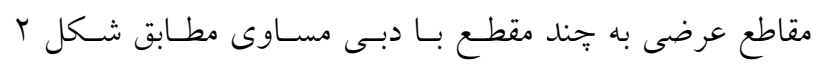
تقسيم مىشوند. اين مقاطع كه داراى دبىهاى مســاوى هسـتند،

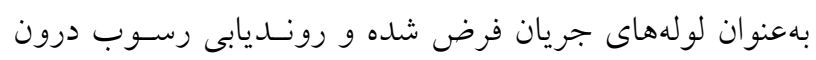

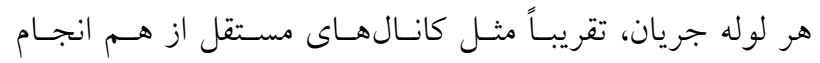

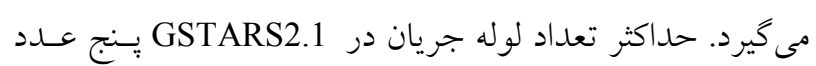

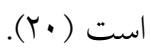

آزاد و شبه دوبعدى بودن مدل مىتواند مورد استفاده قرار كيرد. همجنين طبق بررسى هاى انجام شده رزيم جريان در رودخ مردانه

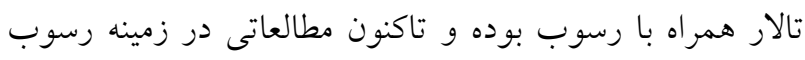
اين رودخانه كه يكى از رودخانههاى دائمى و مهم شمال كشور

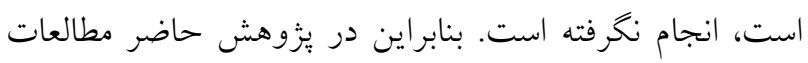

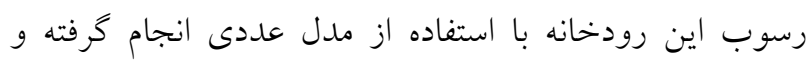
كاريى روابط انتقال رسوب مختلف موجود در مدل GSTARS مورد بررسى قرار كرفت.

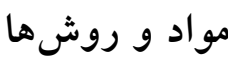
رودخانه تالار

رودخانه تالار از بخشهاى شمالى رشته كوههاى البرز سرجشمه

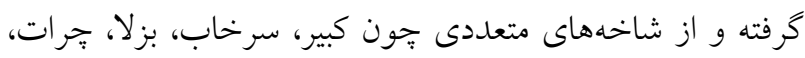

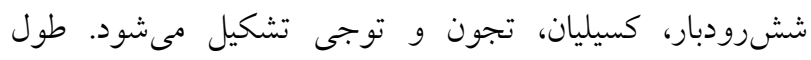

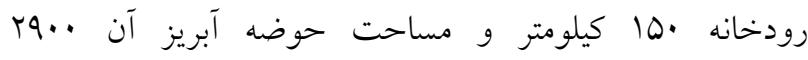
كيلومترمربع است. قسمت اعظم اين حوضه در مناطق كوهستانى

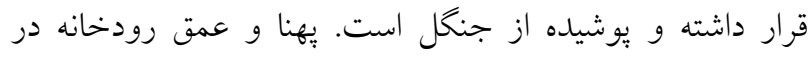

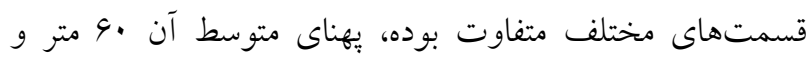

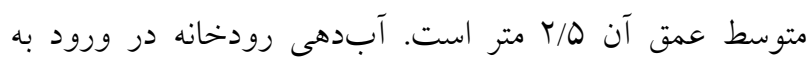
دشت قابل ملاحظه بوده كه بيشتر به مصارف كشاورزى مىرسد اند

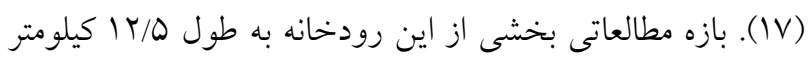

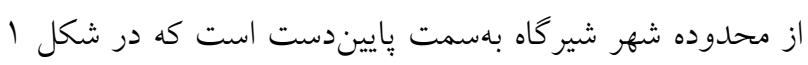
موقعيت آن در تصوير هوايى آمده است.

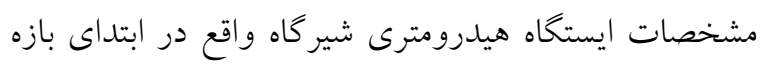

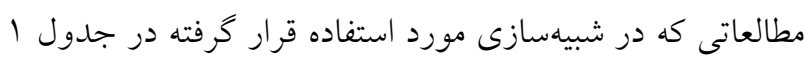
آمده است

\section{معرفى مدل GSTARS و معادلات حاكم}

يكى از مدلهاى رياضى در بخش هيدروليك رسوب، مدل مدل GSTARS (Generalized Sediment Transport model for Alluvial River Simulation) يانگ و موليناس براى براى شبيهسازى رودخانههاى آبرفتى تهيه 


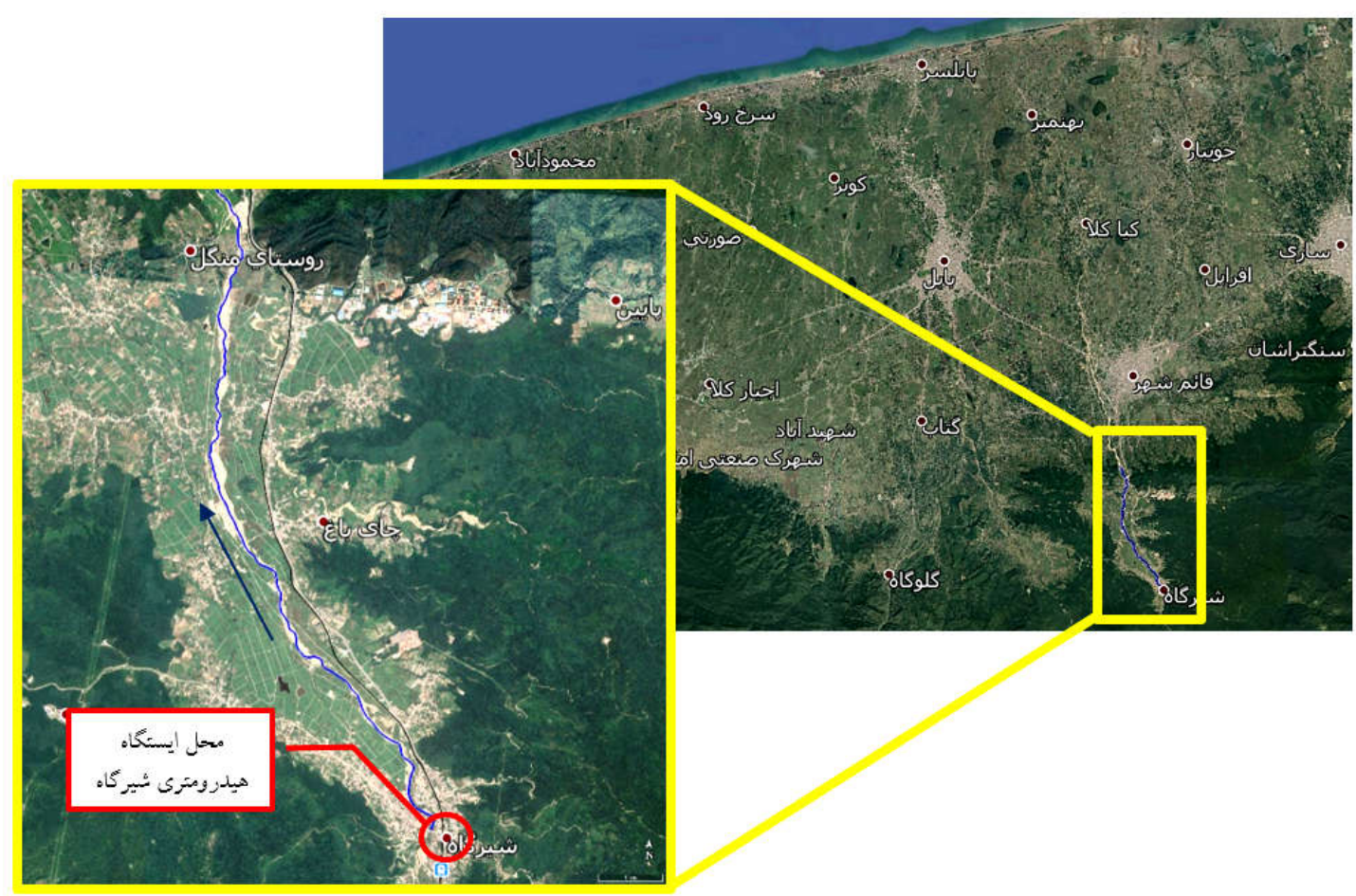

شكل ا. بازه مورد مطالعه و موقعيت ايستخاه هيدرومترى در تصوير هوايى

جدول ا. مشخصات ايستخاه هيدرومترى شير گاه

\begin{tabular}{|c|c|c|c|c|c|c|}
\hline \multirow{2}{*}{ تجهيزات } & \multirow{2}{*}{ نوع ايستكاه } & \multirow{2}{*}{ آرتباع از سطح آزاد } & \multirow{2}{*}{ سال تأسيس } & \multicolumn{2}{|c|}{ موقعيت } & \multirow{2}{*}{ ايستخاه } \\
\hline & & & & $X$ & $\mathrm{Y}$ & \\
\hline اشل، بِل تلفريك و ديتالاكر & درجه يك & YM & Irra & 999490 & $Y \cdot 1 \wedge V \wedge D$ & شير كاه \\
\hline
\end{tabular}

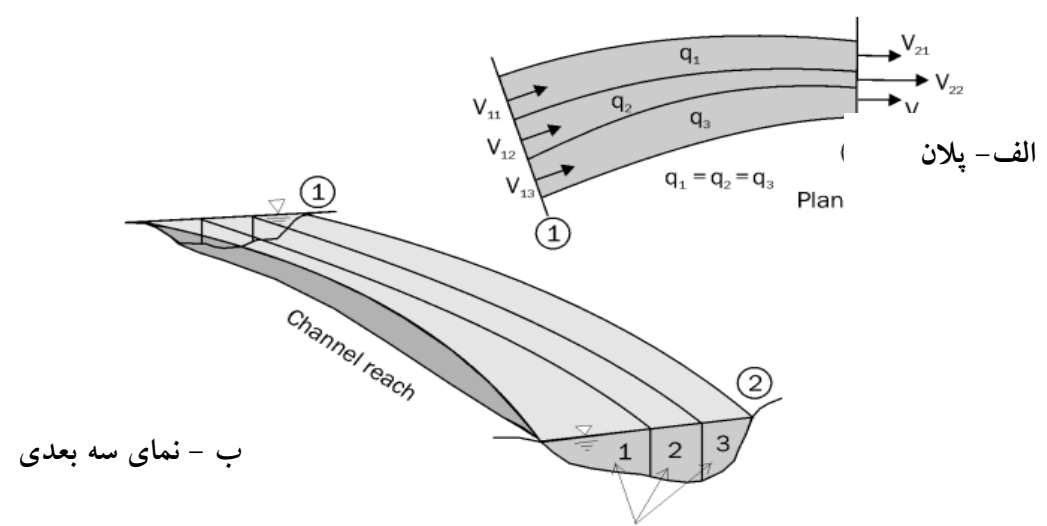

Stream Tubes

(equal conveyance)

شكل r. نمايش شماتيك مفهوم لولههاى جريان مورد استفاده در مدل GSTARS : الف) پِلان و

ب) نماى سهبعدى (Yang and Simões, 2000) 


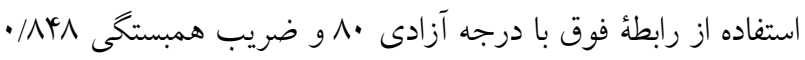
در دو سطح معنى دار او ه درصد، مورد تأييد قرار گرفت (1). يكى ديخراز يارامترهاى مهم در بخش رسوب منحنى دانهبندى بستر رودخانه است. نمودار دانهبندى بستر رودخانه در سه محدوده ابتدا، انتها و ميانه بازه با انجام نمونهبردارى و

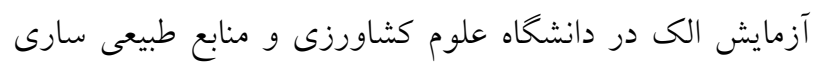
توسط محقق بهدست آمده و مورد استفاده قرار كرفت كه نتايج در شكل ع آمده است. يكى ديخر از قسمتهاى ورودى مدل، انتخاب تعداد لولههاى جريان است. استفاده بيش از يك لوله جريان مدل را در حالت شبهدوبعدى قرار مىدهد. در مطالعه حاضر، شبيهسازى با تعداد مختلف لولههاى جريان نشان داد انتخاب بيش از سه لوله تأثيرى در نتايج حاصل ندارد بنابراين بالوله جريان در انجام شبيهازى مورد استفاده قرار گرفت. در اين زمينه اون و همكاران كه در مطالعات خود بخشى از رودخانه ناكدونخ كره را با استفاده از مدل GSTARS3 مورد مطالعه قرار دادند نيز تعداد سه لوله جريان را توصيه كرده و اظهار

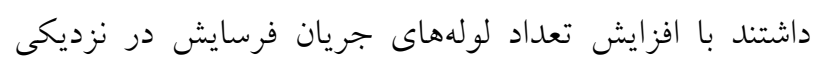
مركز كانال بيشتر از حد تخمين زده مىشود (Y).

\section{نتايج و بحث}

\section{واسنجى و صحتسنجى مدل رياضى}

در مدلسازى عددى، براى انجام صحيح محاسبات، تعداد زيادى از بارامترها مىبايست بهشكل مناسبى تعريف شوند. عمليات تطبيق پارامترها براى هماهنگى و سازكارى مدل در توليد دادههايى همانند نمونه اصلى سيستم، واسنجى مدل يا كاليبره كردن آن مى گويند. صحتسنجى مدل كه به نوعى تأييد مدل نيز است، شامل اثبات اينكه مدل كاليبره شده، براى شرايط شناخته شده در يك دورهُ زمانى متفاوت و وِارامترهاى فيزيكى و توابع تغيير داده شده براى شرايط مورد نظر در دورهُ زمانى جديد به درستى كار مى كند.
يكى از نسخههاى مدل ذكر شده با قابليت واسط گرافيكى است كه بهدليل سهولت وارد كردن دادههاى ورودى، در يُزوهش حاضر مورد استفاده قرار گرفته است. اين مدل نيز با وجود يكبعدى بودن قادر به شبيهسازى شبه دوبعدى و شبه سلبعدى تغييرات هندسه آبراهه است. لئ.

\section{دادههاى مورد نياز در مدل GSTARS2.1} دادههاى مورد نياز اين مدل براى شبيهسازى جريان و رسوب، عبارتند از: دادههاى هندسى، دادههاى هيدروليكى و دادههاى رسوبى. - مان.

در بخش هندسى، يلان عمومى رودخانه همراه با مقاطع عرضى به مدل معرفى مىشود. در مطالعه حاضر از اطلاعات هه مقطع عرضى حاصل از عمليات نقشهبردارى در سال هرrا براى بازهاى به طول 1// ا كيلومتر استفاده

در قسمت اطلاعات هيدروليكى، دبى ماهانه ايستخاه هيدرومترى شير گاه از سال هیץ| تا سال •وسا با گامهاى زمانى •ب روز بهعنوان شرط مرزى بالادست به مدل معرفى شد. براى شرط مرزى ياييندست بهدليل عدم ورجود

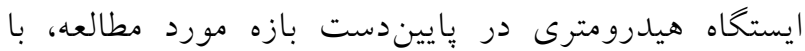
درنظر كرفتن قابليتهاى نرمافزار HEC-RAS، بازه مورد مطالعه با استفاده از اين مدل در حالت ماندكار شبيهسازى و رابطه دبى - اشل استخراج شده در نرمافزار مذكور بهنوان شرط مرزى ياييندست در مقطع انتهايى براى مدل GSTARS مورد استفاده قرار كرفت. بخش رسوب مدل شامل اطلاعات رسوب ورودى، دانهبندى بستر، دما، و يارامترهاى مربوط به انتقال رسوبات جسبنده است. در اين بخش منحنى سنجه رسوب معلق در

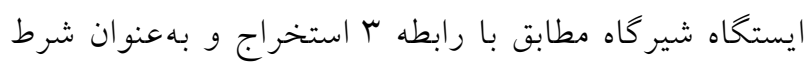
مرزى وروددى مدل معرفى شد (شكل س). $\mathrm{Q}_{\mathrm{s}}=6.312 \mathrm{Q}_{\mathrm{w}}{ }^{1.97}$ Q دبى رسوب معلق د 


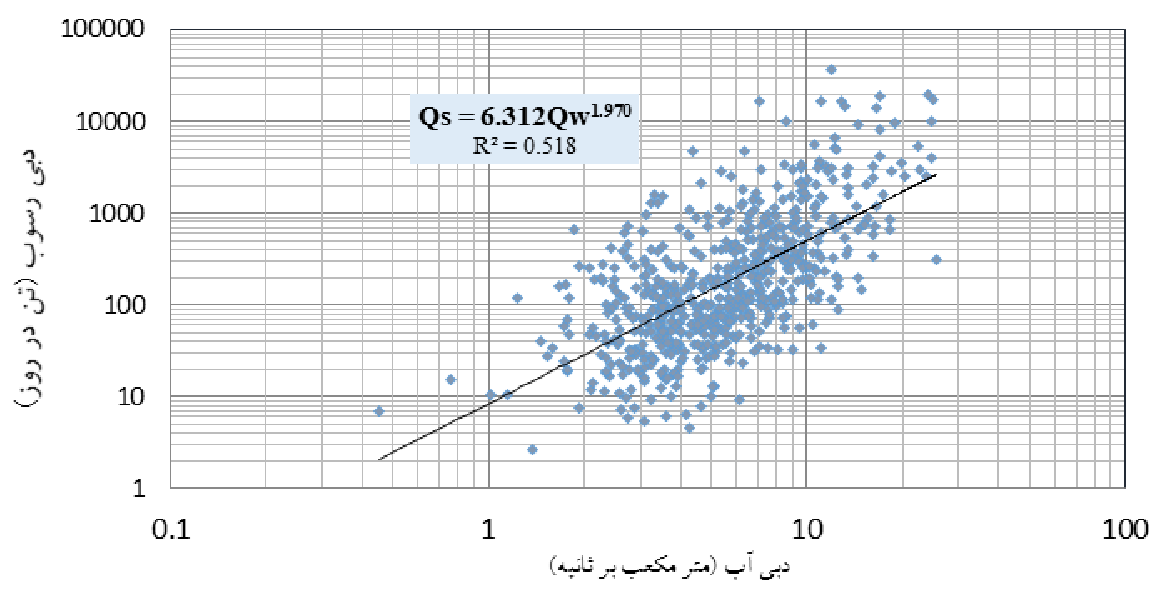

شكل r. منحنى دبى سنجه رسوب در ايستخاه شير كاه

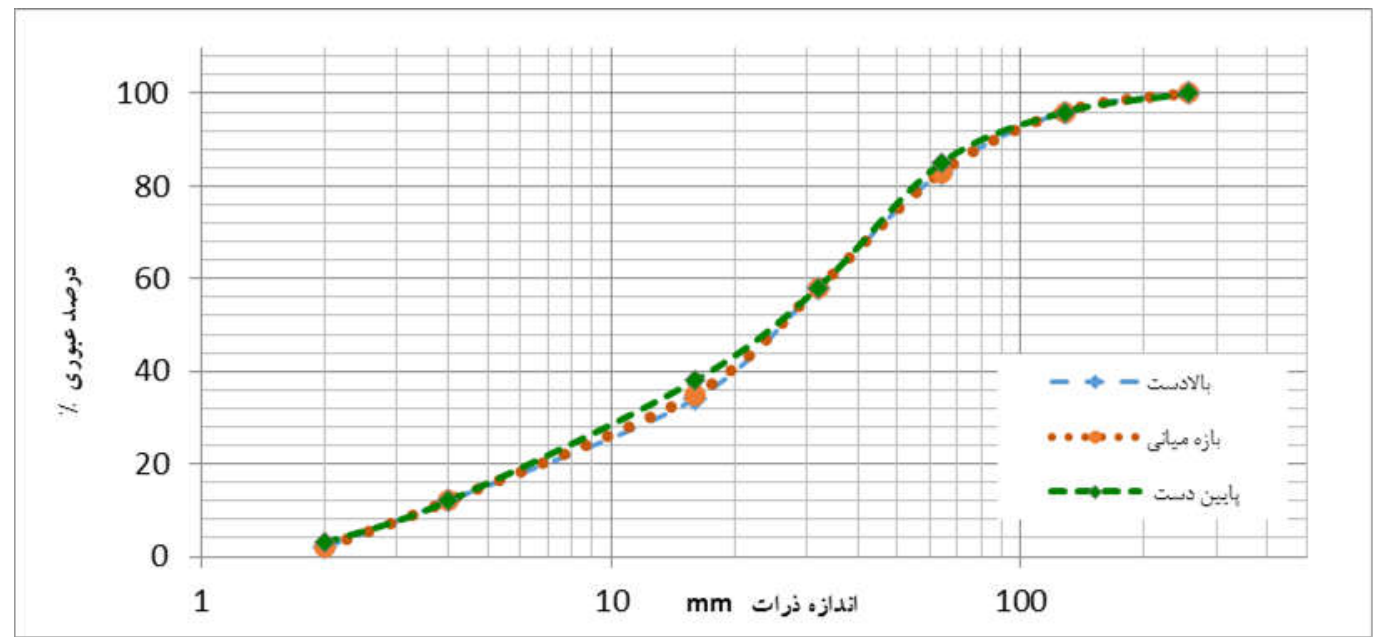

شكل †. منحنىهاى دانهبندى بستر در بازه مورد مطالعه (رنكى در نسخه الكترونيكى)

كه ابتدا واسنجى و صحتسنجى ضريب زبرى در مدل HEC-RAS بازه براى دبى هاى مختلف (محدوده دبىهاى متعارف رودخانها

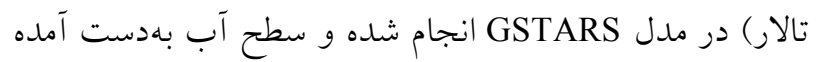

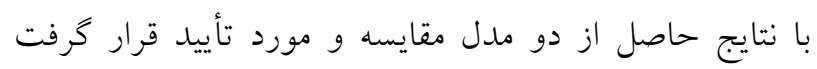

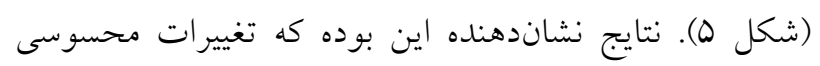

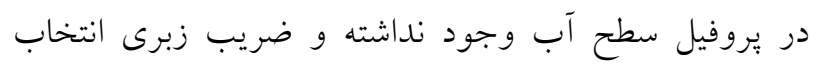
شده براى مدل GSTARS نيز مىتواند مورد استفاده قرار بحيرد.
واسنجى ضريب زبرى در مدل GSTARS ضريب زبرى، مهمترين ضريب هيدروليكى در انواع مطالعات ريت درى مدري

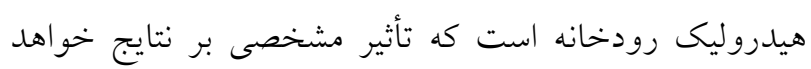

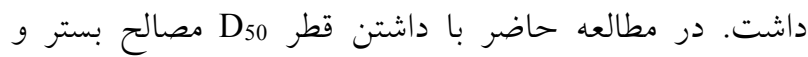
استفاده از روابط تجربى مختلف و بازديد از بازه مورد مطالعه، مقدار ضريب زبرى اوليه براى سواحل و بستر رودخانه درنظر

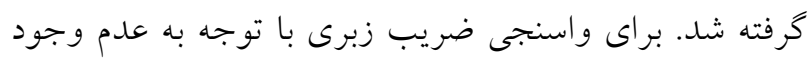

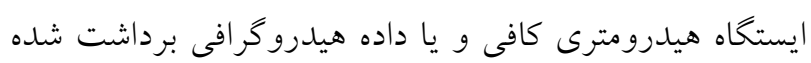

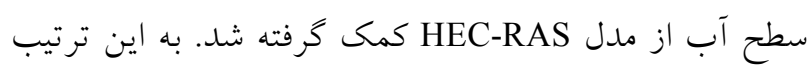



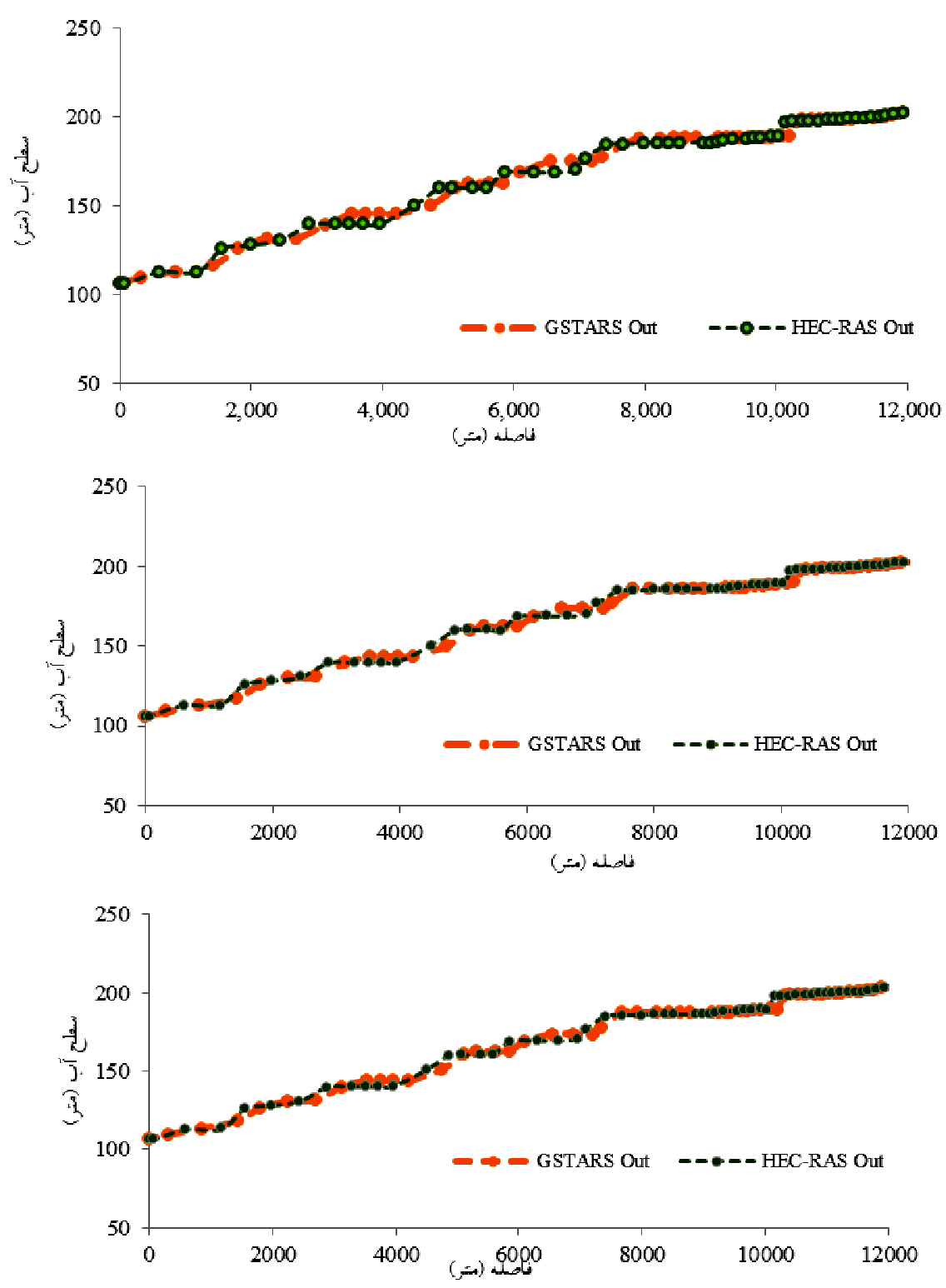

شكل ه مقايسه سطح آب محاسبه شده توسط توسط دو مدل براى: الف) دبى ه مترمكعب بر ثانيه، ب) دبى 10 مترمكعب بر ثانيه و ج) دبى (ب) نـ r مترمعب بر ثانيه (رنغى در نسخه الكترونيكى)

GSTARS2.1 تعداد ه رابطه شامل روابط: يانگ 9V9، يانگ

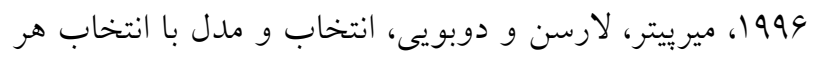

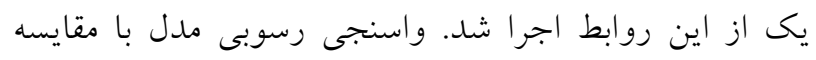
تغييرات بستر حاصل از شبيهسازى و و واقعيت رودخانه انجام روسيط

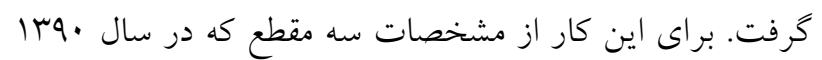

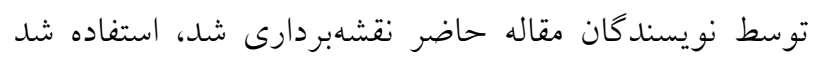

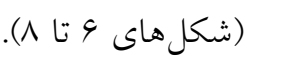

واسنجى و صحتسنجى رسوبى مدل GSRATS 2.1

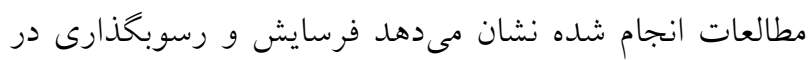

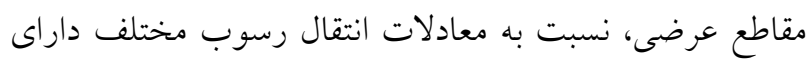
حساسيت است (11). دقت رونديابى رسوب، به معادله حمل بهل معادل رسوب بهكار رفته بستكى دارد. با توجه به اينكه رودخانه تالار

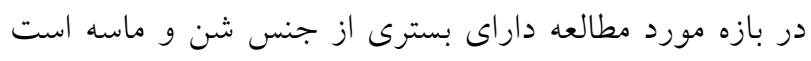

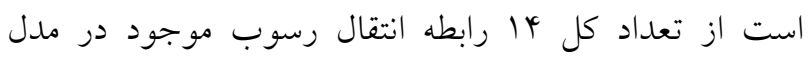




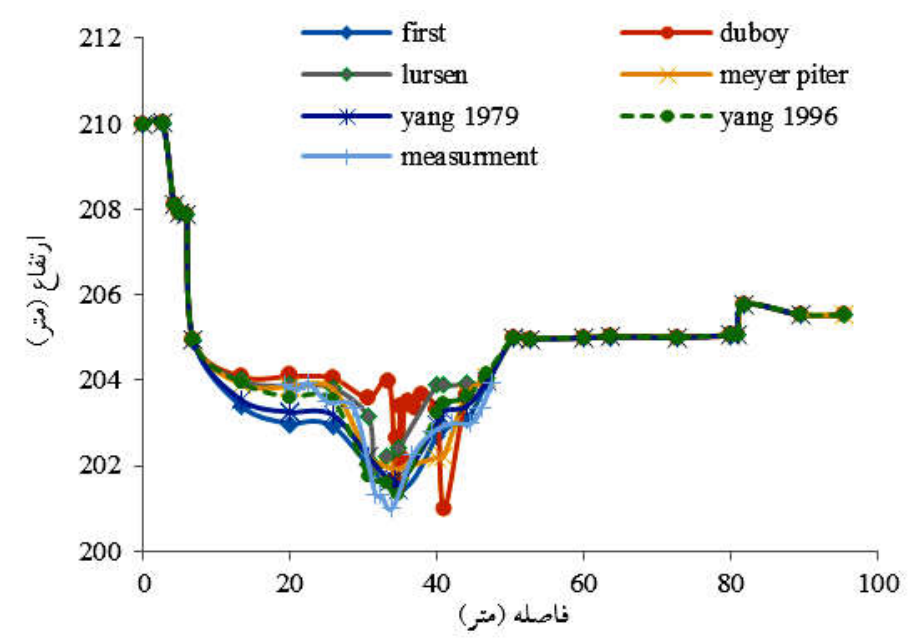

شكل 9. واسنجى روابط رسوبى مختلف در مدل GSTARS براى مقطع عرضى OF (رنكى در نسخه الكترونيكى)

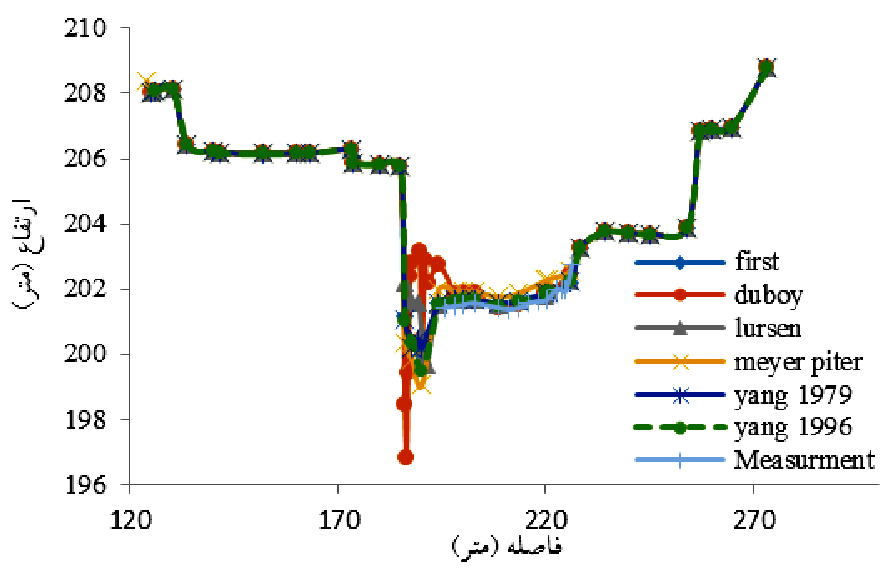

شكل V. واسنجى روابط رسوبى مختلف در مدل GSTARS براى مقطع عرضى لr (رنكى در نسخه الكترونيكى)

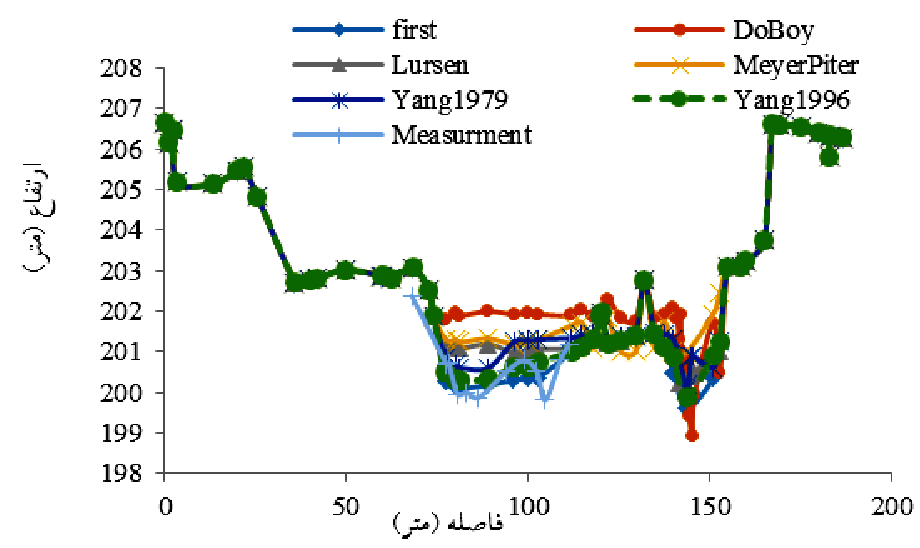

شكل ^. واسنجى روابط رسوبى مختلف در مدل GSTARS براى مقطع عرضى اه (رنكى در نسخه الكترونيكى) 
جدول r. مقادير خطاى استاندارد بهدست آمده براى روابط انتقال رسوب مختلف مورد استفاده در مقاطع ماه، OP و OF

\begin{tabular}{cccccc}
\hline مêc & lursen & DoBoy & Meyer pitter & Yang 1996 & Yang 1979 \\
\hline 51 & 0.688 & 0.655 & 0.655 & 0.654 & 0.665 \\
\hline 52 & 1.293 & 1.298 & 1.297 & 1.201 & 1.302 \\
\hline 54 & 0.798 & 0.743 & 1.026 & 0.637 & 0.733 \\
\hline
\end{tabular}

\begin{tabular}{|c|c|c|c|c|c|}
\hline مقطع & lursen & DoBoy & Meyer pitter & Yang 1996 & Yang 1979 \\
\hline 53 & 1.061 & 0.929 & 0.943 & 0.912 & 0.932 \\
\hline
\end{tabular}

بيشترين خطا را دارد و ميزان فرسايش و افتادگى بستر را بسيار زياد نشان مىدهند كه اين ميزان تغييرات با توجه به مشاهدات و بازديدهاى ميدانى انجام شده غيرقابل قبول است. استفاده از معادله ايكرز و وايت كمترين تغييرات يروفيل طولى رودخانه را خواهد داشت. همجنين در تمامى لئى روابط بخش اعظم نيمه انتهايى بازه در حال فرسايش است.

مدلسازى انجام شده نشان داد شبيهسازى رسوبى رودخانه تالار

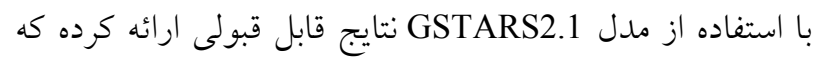

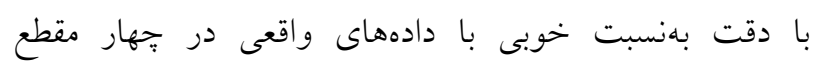

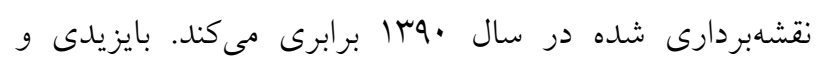

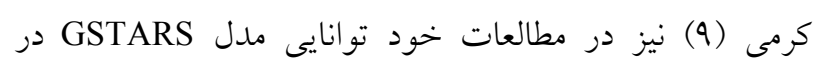
شبيهسازى تغييرات يروفيل طولى و عرضى رودخانه مورد تأييد

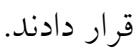
انتخاب صحيح تابع انتقال رسوب مهمترين تأثير را در برآورد

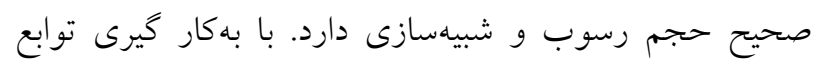

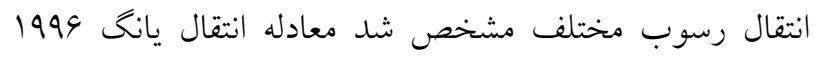
بيشترين انطباق را با واقعيت داشته و مىتواند براى بيشبينى ليش
براى مقايسه نتايج ميزان خطاى استاندارد STE هر يك از توابع انتقال رسوب و دادههاى واقعى برداشت شده بستر رودخانه با مان

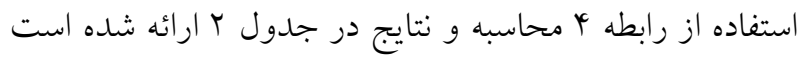

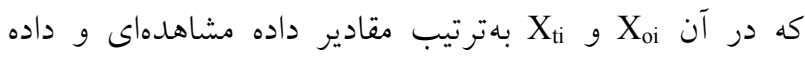
بهدست آمده حاصل از شبيهازى سرى دادهها و N تعداد

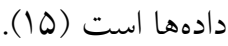
$S T E=\left[\frac{\sum_{i=1}^{i=n}\left(x_{o i}-x_{t i}\right)^{2}}{(n-1)}\right]^{1 / 2}$

همانطور كه در جدول r آمده است، معادله يانگ 1999 داراى ميزان خطاى استاندارد كمترى بوده و به مقادير واقعى نزديكتر

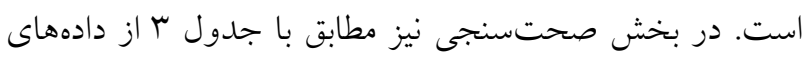

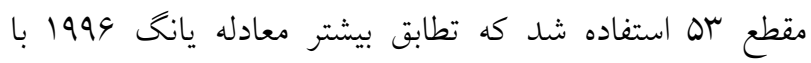
مقادير واقعى را مورد تأييد قرار مىدهد (شكل 9. ه). تغييرات بستر رودخانه در شكل •ا تغييرات يروفيل طولى رودخانه با استفاده از

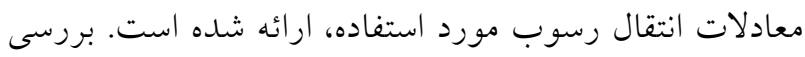
نتايج حاصل از توابع مختلف نشان مىدهد رابطه دوبوى مورد 


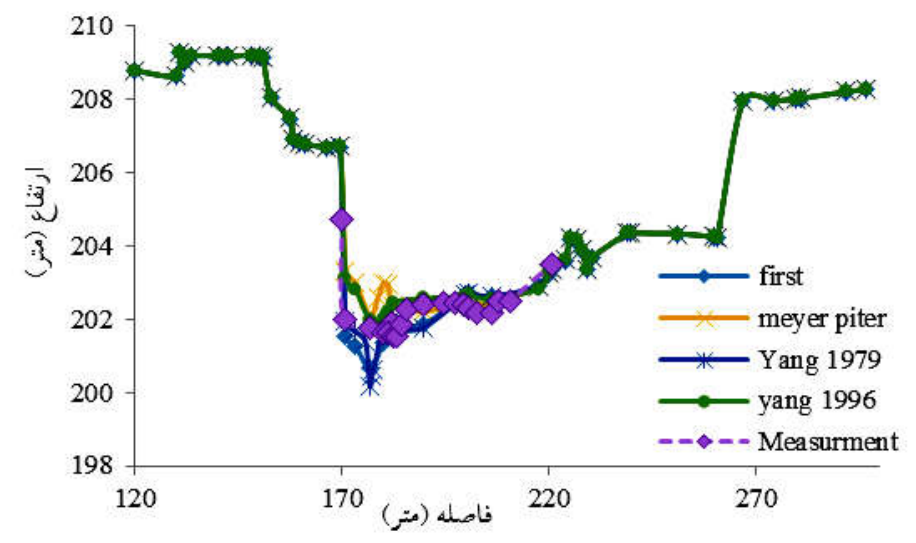

شكل 9. صحت سنجى مدل GSTARS براى مقطع عرضى سه (رنكى در نسخه الكترونيكى)

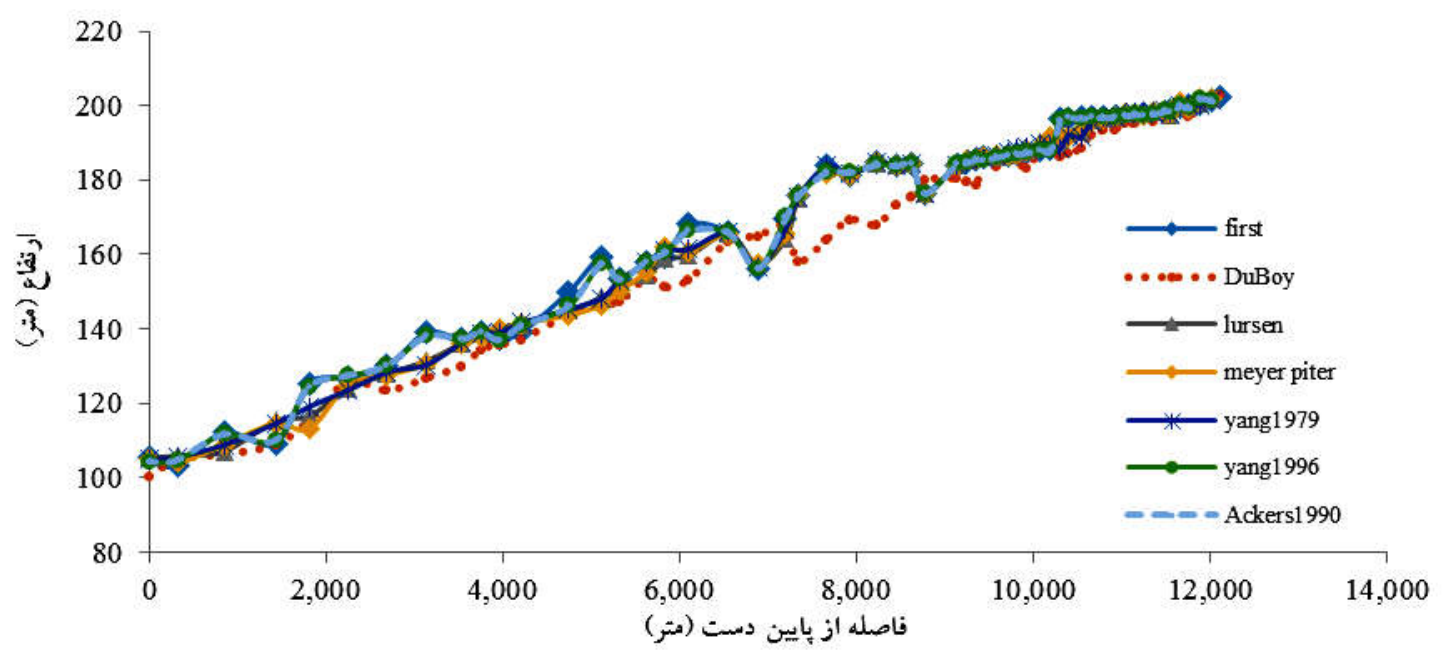

شكل · ا. بروفيل طولى رودخانه با استفاده از توابع انتقال رسوب مختلف (رنخى در نسخه الكترونيكى)

تغييرات اين رودخانه مورد استفاده قرار كيرد. بطنى و همجنين بررسى تغييرات بستر رودخانه تالار نشان داد فرسايش،

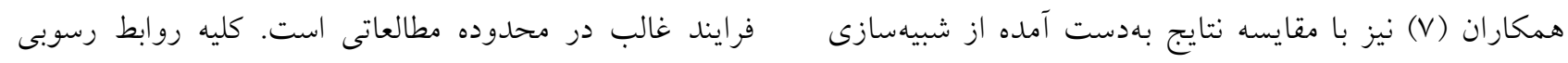

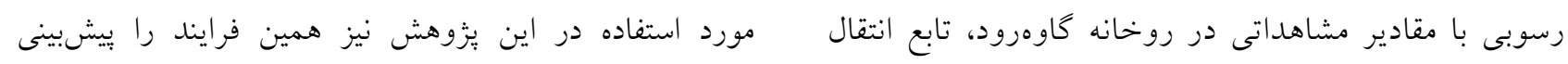

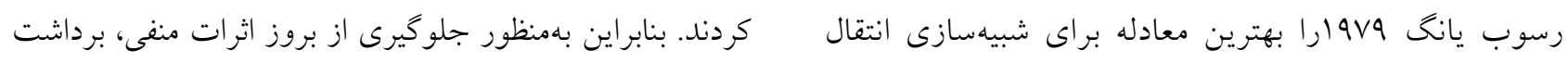

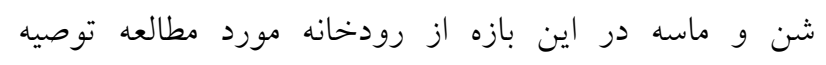
رسوب، معرفى كردند.

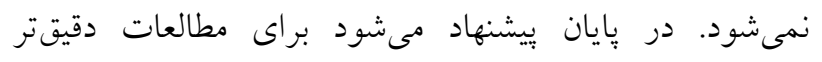

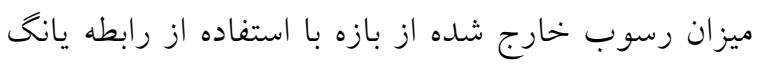

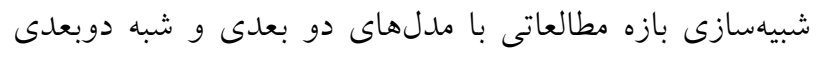

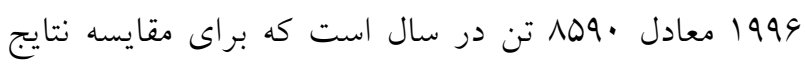
ديخر نيز انجام و مقايسه صورت كيرد. مدلسازى با دادههاى واقعى لازم است در محدوده مورد

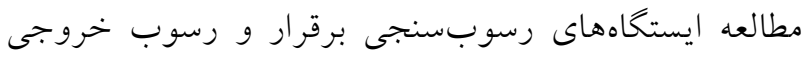

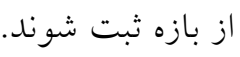


1. Abood, M. M. T., A. H. Mohammed, A. Ghazali and M. Rodzi. 2009. Review study and assessment for sedimentation models applied to impounding reservoirs. Journal of Engineering and Applied Sciences 4(2): 152160.

2. Ahn, J., J. M. Lee, Y. D. Kim and B. Kang. 2019. Effect of climate change on long-term riverbed change using GSTARS model in Nakdong river, Korea. Journal of Civil Engineering. 23: s1849-1859.

3. Albayati, M. A. 2014. Modeling sediment accumulation at kenyir reservoir using GSTARS3. International Journal of Computational Engineering Research (IJCER) 4(10): 2250-3005.

4. AlQasimi, E. and T. Mahdi. 2019. Rivers' confluence morphological modeling using SRH-2D. Proceedings of 2019 International Workshop on Natural Hazards, Pico Island, Portugal.

5. Asadi, F. Z., R. Fazloula and A. R. Emadi. 2017. Investigation of the river bed changes using HEC-RAS4.0 Model Case study: Talar river. Journal of Watershed Management Research 8(15): 25-35. (In Farsi).

6. Azizyan, Gh. R. and R. Mir. 2015. Numerical study of stability of alluvial compound channels using empirical results. Journal of Water and Soil Conservation 22:1. 71-89. (In Farsi).

7. Batny, A., S. H. Golmaee and M. Kh. Zia Tabar Ahmadi. 2015. The study of sediment transport and the changes of river bed using Gstars3 Mathematical model (Case study: Gaveh Roud River). Journal of Water and Soil Conservation 22(1): 191-210. (In Farsi).

8. Bayazidi, M. and N. Karami. 2017. Predicting sedimentation trend in Qareso River using GSTARS3 model. Journal of Environment and Water Engineering 3(1): 66-80. (In Farsi).

9. Chang, H. H., L. Harrison, W. Lee and S. Tu. 1996. Numerical modeling for sediment pass through reservoirs. Journal of Hydraulic Engineering ASCE 122(7): 381-388.

10. Derakhshan, M. 2009. Simulate the behavior of erosion and sedimentation in Ajichay River from GSTARS3 model. M.Sc. Thesis. Mazandaran University. (In Farsi).

11. Gibson, S. 2010. Mobile bed modeling of the Cowlitz River using HEC-RAS: assessing flooding risk and impact due to system sediment. $2^{\text {nd }}$ Joint Federal Interagency Conference, Las Vegas.

12. Hey, R. D. 1986. River response to hydraulic structures. UNESCO. Paris.

13. Joshi, N., G. R. Lamichhane, M. Rahaman, A. Kalra and S. Ahmad. 2019. Application of HEC-RAS to study the sediment. Proceeding of 2019 World Environmental and Water Resources Congress, Pittsburgh, Pennsylvania, U.S.A

14. Khodabakhshi, F. 2012. Comparison of HEC-RAS and GSTARS3 models in the simulation of Sistan River behavior. MSc Thesis, University of Zabol, Department of Water and Soil. (In Farsi).

15. Lapin L. L. 1983. Probability and Statistic for Modern Engineering. $2^{\text {nd }}$ edition, PWS-KENT Publishing Company Boston.

16. Mahdavi, M. 2006. The Applied Hydrology. Volume1. 6 th edition, The Tehran University Book co. (In Farsi).

17. Ministry of Energy. Mazandaran Regional Water. 2009. Engineering comprehensive study of River East Mazandaran province morphology Report. Volume1: Talar River. (In Farsi).

18. Saenyi, W. W. 2003. Temporal and spatial sediment modelling in massing reservoir, Kenya. Die Bodenkultur 54(4): 207-213.

19. Yang, C. T. and J. Ahn. 2011. User's manual for GSTARS 4. Hydro Science and Training Center Colorado State University.

20. Yang, C. T. and F. J. M. Simões. 2000. User's manual for GSTARS 2.1. U.S. Bureau of Reclamation Technical Service Center. Denver. Colorado.

21.Zarrati, A. and A. Etaat. 2010. Comparison of Fluvial-12 and Gstars 2.0 math performance in river behavior simulation. Proceeding of $2^{\text {nd }}$ Congress of Iran Hydraulic, Tehran, Iran. (In Farsi). 


\title{
Evaluation of Efficiency of Sediment Transfer Functions in GSTARS Numerical Model
}

\author{
F. Z. Asadi, R. Fazloula* and A. R. Emadi ${ }^{1}$
}

(Received: May 16-2020; Accepted: February 13-2021)

\begin{abstract}
Investigating and understanding river change issues is one of the important factors in sediment hydraulic sciences and river engineering. These studies can be done with the help of physical, mathematical models, or both, but due to financial and time constraints, mathematical models are more general and often used. In this study, the GSTARS model was used to investigate erosion and sedimentation and select the most appropriate function in $12.5 \mathrm{~km}$ in length from the Talar river in Mazandaran Province. Simulation using the 55 sections taken in 2006, the daily flow data of the hydrometric station of the Shirgah, located at the beginning of the rich and characteristics of the river sediment, was done. The calibration and validation of the model with cross sections taken in 2012 showed that Yang's sediment transport equation has the highest correlation with reality and can be used to predict river change. The amount of sediment depleted from the case study using the Yang equation is estimated at 8590 tons per year. Also, the study of longitudinal profiles of the river with different sediment transfer functions showed that the study reach at the end range has an erosion trend and is not capable of sand and gravel mining.
\end{abstract}

(

Keywords: Bed changes, Talar river, Numerical simulation, Erosion and sedimentation, Sediment calibration

1. Water Engineering Department, Sari Agricultural Sciences and Natural Resources University, Sari, Iran.

Corresponding author, Email: raminfazl@yahoo.com 